Article

\title{
Information Literacy, an Investigation into Students' Access and Use of Information in an Academic Institution in Ghana
}

\author{
Franklina Adjoa Yebowaah ${ }^{1,}{ }^{*}$, Simon Sanche ${ }^{2}$ \\ ${ }^{1}$ SDD University of Business and Integrated Development Studies (SDD-UBIDS) Library, Ghana \\ 2 Dr Hilla Limann Technical University, Ghana \\ *Correspondence: ayeboaah123@gmail.com
}

How to cite this paper: Adjoa Yebowaah, F., \& Sanche, S. (2021). Information Literacy, an Investigation into Students' Access and Use of Information in an Academic Institution in Ghana. Open Journal of Educational Research, 1(1). Retrieved from https://www.scipublications.com/journal/index.php/ojer/article/view/109

Received: July 20, 2021

Accepted: August 24, 2021

Published: August 25, 2021

Copyright: (c) 2021 by the authors. Submitted for possible open access publication under the terms and conditions of the Creative Commons Attribution (CC BY) license (http://creativecommons.org/licenses /by/4.0/).

\begin{abstract}
In modern times, a lot of light has been thrown on Information literacy by empirical studies due to its significant role in facilitating access to information and use as well as lifetime learning. It is one of the main factors responsible for the information explosion and a key determining factor for students' success in academics. The study gauged students' attitudes on the IL programmes of the University for Development Studies (UDS) using both qualitative and quantitative research approaches. The study discovered that students did not consider the library as a source of academic knowledge and information since their frequency of visiting was low. The study also showed that $43.1 \%$ of the respondents go to the library at least once a week while the majority $(56.9 \%)$ of the respondents either visited the library once a month or not at all. Early Childhood and Basic Education, Development Education, Social Change Communication and Renewable Natural Resources, are the courses pursued by those who utilized the library every day. Alternatively, no student pursuing B. Ed Business Studies made use of the library daily and $48.6 \%$ of them did not enter the library at all. The majority (58\%) of the respondents had not been oriented on the use of the library. It was realized that $49.8 \%$ were knowledgeable of the fact that electronic resources are available in the library. The remaining (50.2\%) did not have any knowledge of electronic resources in the library and were unlikely to make use of them. The utilization of electronic resources also varied according to programmes of study. Students who had comparatively higher access to such resources were pursuing Early Childhood and Basic Education. The study also realized that students' interest in participating in Information Literacy programmes in the university increased and this increased the quality of their information literacy skills. With their awareness and know-how in information literacy, they can use the internet to retrieve the necessary information for academic work. The study makes some recommendations, Principals and Deans should coordinate to organize more Information Literacy Programmes, increased staff participation in the teaching of the IL Programmes and lastly, implementation of Academic Board pronouncements on the IL Programme. This will go a long way to improve access and enhance the use of information in the university.
\end{abstract}

Keywords: Information Sources, Information Access, Students' Academic Performance

\section{Introduction}

One of the most significant factors as far as information explosion is concerned is Information literacy. Information literacy has made it possible for individuals to cope with challenging situations by making it possible for them to know when information is needed, where it can be to be found, how to utilize it correctly and efficiently [1]. Other principal features of information literacy include the capacity to identify the needed information and being mindful of the laws that regulate its use [2]. Numerous studies show that information literacy is crucial to students' academic success [3-6]. 
Information literacy programmes in institutions of higher learning have furnished students with the ability to pinpoint their information requirements, find the desired information, assess the credibility and trustworthiness of the obtained information as well as know the ethical and legitimate matters about the use and reproduction of the information [4]. Regardless of the crucial role information literacy play, several students at the undergraduate level do not know what Information Literacy entails and has hence been transformed into information illiterates [7]. According to [8], students with inadequate knowledge of intellectual property rights are often involved in plagiarism as a result of the wrongful use [9] of information, deceit and misapprehension of the text. This has resulted in grave consequences for the students involved. Information literacy for the abovementioned reasons require policy attention and should therefore be encouraged and promoted in institutions of higher education since it is the only path to escape the effects of lack of information and the repercussions of wrongful use of information.

The information offered throughout various public libraries, community resources, special interest organizations, media outlets and the internet is unmistakably in unfiltered format, therefore, raising concerns about its genuineness, validity and dependability [3]. Words or phrases that aid to retrieve the desired information is very essential to any person considered to be information literate; [4]. The nature and scope of the required information are determined by the one looking for the information for academic work, research and group presentations. This enables the student to advance his or her ability to discover, assess, utilize and share appropriate information. The ability to competently use informational resources is a crucial skill for all students [10].

The world has become a global village where information is readily available from every place worldwide and to obtain this information for learning, Information literacy is critical. With the rapid advancement in Information and Communication Technologies (ICTs), the information environment has grown gradually more complex. Educational institutions are giving credence to the needs of learners for them to engage with the information environment as an integral part of the learning process. The information landscape is always evolving with regards to its volume, storage capacity, retrieval speed, as well as the way it is transferred [11]. The amount of information obtainable by users in such situations is not only increased but also generates a complex environment for them with regards to locating, retrieving and evaluating the information. The development of the internet and other web technology has certainly improved access to information but that does not mean that people will have the competence to access it for use [12]. The ability of information seekers and users to obtain and use information efficiently highly depends on their information literacy level. Many libraries and universities in Ghana have introduced information literacy programmes to better equip people for this information age by instituting various training sessions. It is against this background that, the current study seeks to investigate students' access and use of information in an academic institution in Ghana.

\section{Materials and methods}

\subsection{Research Design}

A descriptive research design was adopted for this research and was used to analyze the attitude of students to information literacy programmes in the University for Development Studies. According to [13] as well as [14], descriptive research deals with relationships that exist, such as the state of prevailing situations, practices and trends that occur in specific environments. Students' information literacy skills, attitudes towards training programmes on information literacy and outcomes of information literacy programmes in the University for Development Studies was obtained using the descriptive research design. This research design also gave an insight into the problems that affect information 
literacy programmes of undergraduate students as well as students' mindfulness of the legal and ethical repercussions of information use.

According to [13] and [15], there are three research approaches in social science, qualitative, quantitative and mixed methods. The use of words and closed-ended questions for qualitative and also numbers and open-ended questions for quantitative is the difference between the two. This study adopted the mixed methods approach. A mixed-method approach according to [15] belongs to the mid-point of this range because it combines aspects of both qualitative and quantitative research approaches. [15] further added that in social science mixed methods approach also referred to as triangulation combines both the qualitative and quantitative forms. [16] also notes that triangulation empowers the researcher to acquire information from different sources to answer research questions from different angles. The adoption of mixed methods allowed the researcher to investigate using both qualitative and quantitative methods. Responses from students generated the quantitative data which were analysed using quantitative methods while qualitative data obtained from interviews of staff members were analysed using qualitative methods. Quantitative research method was the major research approach while qualitative research was used as support.

\subsection{Study Area and population}

The study area used for this research is the University for Development Studies (UDS) in Tamale in the northern region of Ghana. The university was selected because it recently automated its library and it is also a subscriber to various electronic resources and databases [17]. Information Literacy training programmes are held regularly for students in the Faculty of Agribusiness and Communication Science, Faculty of Education, Faculty of Agriculture, and the Faculty of Renewable Natural Resources. For this reason, the researcher used three of the departments in the faculty of Education for the study. The departments used include Business Studies education, Social Science Education, Development education and Early childhood and Basic education. The enrolment of undergraduates offering Information Literacy Programmes for the 2016/2017 academic year was used for the study. This is because they had already gone through some training and were in a better position to answer questions for this study. There were 799 students as shown in Table 1(University for Development Studies 2018).

\subsection{Selection of sample}

The sample size was carefully chosen from a population of students offering information literacy in the Tamale, Wa and Nyankpalla campuses of the University of Development Studies. According to [18], the formula for determining the sample size is:

$$
\mathrm{n}=\frac{N}{1+N(e)^{2}}
$$

"Where $\mathrm{n}=$ sample size; $\mathrm{N}=$ sample frame and $\mathrm{e}=$ error or significance level.

An error level of \pm 0.05 or \pm 0.10 (i.e., 5 or 10 percentage points) is traditionally acceptable according to Ahuja (2001).

In this study, $\mathrm{N}=799$ and $\mathrm{e}=5 \%=0.05$. Therefore:"

$$
\mathrm{n}=\frac{799}{1+799(0.05)^{2}}=267
$$

A sample size of 267 undergraduate students obtained from the formula above was used for this research. Sampling techniques such as probability and non-probability methods of sampling were adopted for this study. The stratified sampling method was used to choose respondents at the three different campuses of UDS for this study. Stratified sampling as posited by [19] is a probability sampling method in which all participants in the population have the same chance of being chosen. The cluster probability sampling technique was also used to carefully choose academic members of staff who teach information literacy within the institution. The last sampling method used by the researcher was the 
purposive non-probability sampling technique. This was used to get a sample of academic librarians for the research. A purposive sampling technique according to [20] is a type of non-probability sampling method where the researcher deliberately chooses participants who are relevant to the research. Those chosen included the Senior Assistant Librarians and Assistant Librarians who are teachers of undergraduate students.

\subsection{Data collection procedure}

A blend of data collection methods was utilized to gather both primary and secondary data. This is because using a blend of data collection techniques ensures the reliability and validity of the data collected. Countless sources of secondary data including published and unpublished sources for instance journals, research reports, books, dissertations, seminars, conference proceedings and websites were used for the study. Questionnaires containing closed and open-ended questions were given out to obtain primary data. The key method through which data was collected from undergraduate students was through the questionnaires. The questionnaires consisted of questions to which respondents were required to answer individually in writing. 267 questionnaires were given out to students to obtain the data. Interview questions were thoughtfully structured to elicit answers for the specific objectives of the study.

\subsection{Data Analysis}

Quantitative data obtained were analyzed using Statistical Package for Social sciences (SPSS) version 20 for data. The qualitative data was also sorted into thematic areas with a matrix then subjected to content analysis. Answers from the questionnaire were coded with numerical values and analysed with SPSS version 20. Questionnaires were numbered one after the other in the order in which they were received. Demographic characteristics of the respondents and other basic features were obtained using Descriptive statistics. These were demonstrated with figures, percentages and frequencies. Relevant percentages and frequencies were displayed in tables and charts.

\subsection{Ethical consideration}

The study is aimed at adding to the existing knowledge on undergraduate students' attitudes towards information literacy programmes of the University for Development Studies. The consent of all Respondents was sought before taking part in the study. All respondents were also assured of the confidentiality of their responses and were not obliged to write or state their names on the questionnaires and the interviews respectively. Most importantly permission was sought from the registrar of UDS before data collection began.

\section{Results}

\subsection{Students' Access and Use of Information}

This section presents the results of students' access and use of information. Key variables presented included the frequency of students visiting the library, the purpose of visiting the library, library assistance offered to students, and students' awareness of electronic resources in the library. Other issues presented under this section included students participation in the information literacy programme, their knowledge of information sources, and access and use of the internet among the students.

\subsection{Frequency of Visiting the Library}

One of the ways of measuring students' access to and use of information is their frequency of visits to the University's library. It was discovered that the frequency of using the University's library varied from student to student. The results shown in Figure 1, indicated that $25(9.4 \%)$ respondents visited the library every day. This means that is this was the category of students that had frequent access and use of academic information. They probably had considered the library as a place for learning and conducting their 
research and hence visiting it became a daily habit. This was expected to grant them access to valuable information as they become familiar with the resources in the library as well as assistance, they received from the library staff.

Besides, 90 (33.7\%) respondents visited the University's library at least once every week. This category of people also had access to information once they visited it weekly. This also means that the students who visited the library weekly had not considered the library as a place where they learned daily but probably visited it only when they needed valuable information. It was also found that $87(32.6 \%)$ respondents visited the library once a month. This category of people were not regular users of the library but only visited the library occasionally to look for information. Such people were likely not to become familiar with new developments of the library and hence may lack access to vital information. Further, $4(1.5 \%)$ respondents claimed that they visited the library once a Trimester. Finally, 61 (22.8\%) respondents did not visit the library at all. Such people did not know the academic information that was kept at the library and hence had no opportunity of using the library's information to enhance their work.

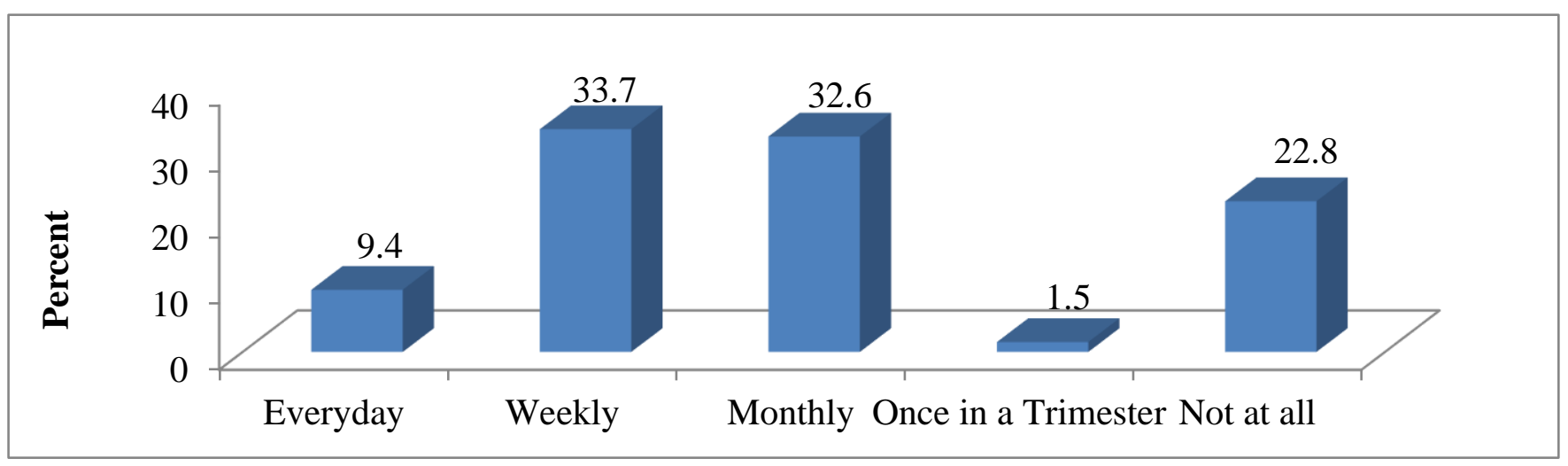

Figure 1. Frequency of Visiting the library. Source: Field Survey (2019)

Table 1. Academic Programmes of Study and Frequency of Visiting the Library

\begin{tabular}{|c|c|c|c|c|c|c|}
\hline \multirow{2}{*}{$\begin{array}{l}\text { Academic Pro- } \\
\text { gramme }\end{array}$} & \multicolumn{5}{|c|}{ Frequency of Visiting the library } & \multirow[t]{2}{*}{ Total } \\
\hline & Everyday & Weekly & Monthly & $\begin{array}{l}\text { Once in a } \\
\text { Trimester }\end{array}$ & Not at all & \\
\hline $\begin{array}{c}\text { Agricultural Tech- } \\
\text { nology }\end{array}$ & $1(9.1 \%)$ & $6(54.5 \%)$ & $2(18.2 \%)$ & $0(0.0 \%)$ & $2(18.2 \%)$ & $11(100 \%)$ \\
\hline $\begin{array}{l}\text { B.ED Business Stud- } \\
\text { ies }\end{array}$ & $0(0.0 \%)$ & $7(20.0 \%)$ & $11(31.4 \%)$ & $0(0.0 \%)$ & $17(48.6 \%)$ & $35(100 \%)$ \\
\hline B.ED Social Science & $4(7.5 \%)$ & $23(43.4 \%)$ & $17(32.1 \%)$ & $2(3.8 \%)$ & $7(13.2 \%)$ & $53(100 \%)$ \\
\hline $\begin{array}{l}\text { Development Edu- } \\
\text { cation }\end{array}$ & $9(11.5 \%)$ & $22(28.2 \%)$ & $24(30.8 \%)$ & $2(2.6 \%)$ & $21(26.9 \%)$ & $78(100 \%)$ \\
\hline $\begin{array}{c}\text { Early Childhood \& } \\
\text { Basic Education }\end{array}$ & $4(13.3 \%)$ & $13(43.3 \%)$ & $11(36.7 \%)$ & $0(0.0 \%)$ & $2(6.7 \%)$ & $30(100 \%)$ \\
\hline $\begin{array}{c}\text { Renewable Natural } \\
\text { Resource }\end{array}$ & $2(12.5 \%)$ & $5(31.2 \%)$ & $3(18.8 \%)$ & $0(0.0 \%)$ & $6(37.5 \%)$ & $16(100 \%)$ \\
\hline SCC & $5(11.4 \%)$ & $14(31.8 \%)$ & $19(43.2 \%)$ & $0(0.0 \%)$ & $6(13.6 \%)$ & $44(100 \%)$ \\
\hline Total & $25(9.4 \%)$ & $90(33.7 \%)$ & $87(32.6 \%)$ & $4(1.5 \%)$ & $61(22.8 \%)$ & $267(100 \%)$ \\
\hline
\end{tabular}


Further analysis was done to compare how students visited and used the University Library. These varied by academic programmes of the students. This was done by generating cross-tabulation of library visits and academic programmes. Chi-square test of independence was used to test the claim that students' visits to the library were independent of their academic programmes of study. The results generated are shown in Table 1.

The Chi-square statistics revealed a test value of 38.57 and this was found to be significant at $5 \%(p$-value $=0.030<0.05)$. This provides enough evidence to reject the claim of independence of students' academic programmes and library visits and hence students' academic programmes of study influence the frequency of their library visits. The frequencies and relative percentages shown in Table 1 also support the findings that the frequency of library visits varied according to students' academic programmes of study. For example, among those that visited the library every day were students pursuing Development Education, Early Childhood and Basic Education, Renewable Natural Resources, and Social Change Communication. On the other hand, none of the students pursuing B.ED Business Studies visited the library every day and the majority of them did not visit it all.

\subsection{Purpose of Visiting the Library}

Table 2. Purpose of Visiting the Library

\begin{tabular}{|c|c|c|}
\hline Purpose & Frequency & Percent \\
\hline For reading of one's notes & 86 & 32.2 \\
\hline For reading storybooks & 19 & 7.1 \\
\hline For reading textbooks & 61 & 22.8 \\
\hline For research on coursework & 108 & 40.4 \\
\hline To look for specific information when needed & 50 & 18.7 \\
\hline To read newspapers & 6 & 2.2 \\
\hline
\end{tabular}

Source: Field Survey (2019)

The respondents provided several reasons for visiting the library. From Table 2, the main purpose of their visit to the library included visited the library to read different kinds of books, research for coursework, and search for specific information when needed. Table 2 specifically revealed that $86(32.2 \%)$ visited the library to read their notes taken during lectures, $19(7.1 \%)$ visit the library to read storybooks, $61(22.8 \%)$ visited the library to read textbooks, while 108 (40.4\%) visited the library researching coursework. Other purposes discovered included going to the library to search for some specific information as was indicated by $50(18.7 \%)$ of the respondents and finally, a small proportion $6(2.2 \%)$ visited the library to read newspapers.

The respondents were asked to indicate whether their purpose of visiting the library had been achieved. Multiple responses were considered in this section. The respondents generally suggested that they had been achieving their purpose of visiting the library. From Table 3, (61)70.9\% of those who visited the library to read their notes claimed that they had achieved their purpose of going there. This means they made effective use of the library, as according to them, it helped them to revise their notes and get supplementary information from the library conveniently.

Further, among the respondents who visited the library to read storybooks, the majority of the $16(84.2 \%)$ indicated that they had achieved their purpose of going to use the library while the remaining $3(15.8 \%)$ felt that the library facility had not been helping them to achieve their purpose of going there. Further evidence suggested that the library had relevant textbooks that supported students' research and search for information for their coursework materials. From Table 3, 43 (70.5\%) of those who visited the library to read textbooks have been achieving their purpose of going there. Similar findings had been found for those who either visited the library to search for coursework materials or 
to search for specific information on a subject matter. From Table 3, $74(68.5 \%)$ and 39 (78\%) of the respondents were found to have achieved their purpose for going to the library for research on course work and finding specific general information respectively.

Table 3. Achieving Purpose of Visiting the library

\begin{tabular}{|c|c|c|c|c|c|c|}
\hline \multicolumn{7}{|c|}{ Finding Needed Information in the library } \\
\hline & \multicolumn{2}{|c|}{ Yes } & \multicolumn{2}{c|}{ No } & \multicolumn{3}{c|}{ Total } \\
\hline Purpose of Visiting library & Freq & \% & Freq & $\%$ & Freq & $\%$ \\
\hline Visit the library to read my notes & 61 & 70.9 & 25 & 29.1 & 86 & 100.0 \\
\hline For reading of story books & 16 & 84.2 & 3 & 15.8 & 19 & 100.0 \\
\hline For reading textbooks & 43 & 70.5 & 18 & 29.5 & 61 & 100.0 \\
\hline For research on coursework & 74 & 68.5 & 34 & 31.5 & 108 & 100.0 \\
\hline $\begin{array}{c}\text { looking for specific information } \\
\text { when needed }\end{array}$ & 39 & 78.0 & 11 & 22.0 & 50 & 100.0 \\
\hline To read news papers & & & & & & 6 \\
\hline
\end{tabular}

Source: Field Survey (2019)

Finally, students have not been achieving their purpose of visiting the library to read newspapers. From Table 3, only 2 (33.3\% out of the 4 (66.7) respondents who visited the library to read newspapers had achieved their purpose. What could be the reason is that the University library probably had not got a current or adequate number of newspapers in its collection in line with students' needs.

\subsection{Library Assistance}

The respondents were asked to indicate whether they often received assistance from the library staff regarding access and use of the library. The results as shown in Figure 2 indicated that $138(51.7 \%)$ respondents confirmed that they had received support in the form of instruction and guidance from the library staff regarding the use of the library. The remaining $129(48.0 \%)$ respondents did not receive any support or did not even use the library facility.

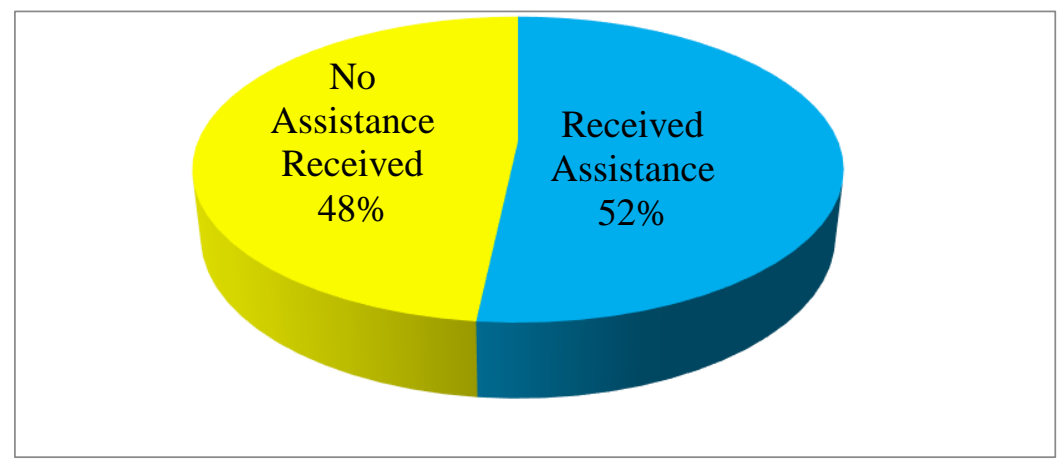

Figure 2. Receiving Support from Library Staff. Source: Field Survey (2019)

The respondents who received assistance from library staff in using the library had listed the kinds of support or assistance received. The frequency and percentages of the distribution are shown in Table 4. From Table 4, the main assistance received by students were in the area of activation of a library card, basic library ethics, cataloguing, database research, accessing the library, how to borrow a book, how to retrieve information, general library orientation and instruction on research methodology.

The findings in Table 4 indicate that $111(41.57 \%)$ respondents had received assistance from the library in connection with their library cards activation. The library card is 
very important for users of the library because it was an identity card that students often used to access services of the library. The library card can only be obtained by the student himself/herself with the assistance of library staff. The fact that 58 (43\%) had not received any assistance on activation of library cards suggested that they were not effective users of the library.

The findings in Table 4 shows that 138 (51.69\%) respondents indicated that they received support in the form of orientation in the area of basic library ethics which is part of the University for Development Studies curriculum to offer orientation to Level 100 students on the use of the library to facilitate students' familiarity with access and use of the library. Such a programme involves showing students the process of identifying library materials, and where to seek support when needed. Besides, students could go to the library staff to seek more knowledge on the basic ethics of the library. The fact that such basic orientations had been given to students especially, during their first-year orientation, makes it the dominant support often received as reported in Table 4.

It was also discovered that $84(31.46 \%)$ received assistance on the use of the library catalogue while $76(28.46 \%)$ received assistance on how to access key reference materials in the library. Assistance on how to borrow a book and how to locate a book were indicated by115 (43.07\%) and $117(43.82 \%)$ respectively. This means that the UDS Campus Libraries had been performing crucial roles in assisting students to locate and access or borrow books. However, less than $50 \%$ of the respondents had accessed these services, and this implies that despite the crucial role of library staff, the students themselves have not considered library services as an important process of improving their information literacy skills.

Table 4. Kinds of Instructions

\begin{tabular}{|c|c|c|}
\hline Kinds of Assistance & Frequency & Percent \\
\hline Activate library card & 111 & 41.57 \\
\hline Basic library ethics & 138 & 31.69 \\
\hline The use of the catalogue & 84 & 4.46 \\
\hline Database research & 11 & 28.46 \\
\hline How to access the library & 76 & 43.07 \\
\hline How to borrow a book & 115 & 43.82 \\
\hline How to locate books & 117 & 23.22 \\
\hline How to retrieve electronic information & 62 & 49.06 \\
\hline Librarian orientation & 131 & 4.12 \\
\hline
\end{tabular}

Source: Field Survey (2019)

\subsection{Awareness of Electronic Resources and Database}

The respondents were asked to indicate whether they were aware of electronic resources in the University library. The results obtained, as shown in Table 5, indicated that $133(49.8 \%)$ respondents claimed that they were aware of the electronic resources in the library. Cross-tabulation of students' academic programmes of study and awareness of electronic resources were generated and tested for independence using the Chi-square test. The proportion of respondents who were aware of the availability of these resources was almost the same as those who were not aware. The results of a chi-square test of independence were found not to be significant even at $5 \%$ ( $p$-value $>0.05)$. This means that awareness of electronic resources did not vary by programmes of study.

From Table 5, the majority 134 (50.2\%) of the students from the various programmes were not aware of the electronic resources in the library. It was, however, expected that most of the students would have become more aware of the electronic resources in the 
library since information about the materials were normally communicated to the students during their first-year orientation. This means that the 133 (49.8\%) awareness rating was not sufficiently large enough once students were informed of the availability of such electronic resources and were thus expected to be using them.

Table 5. Awareness of Electronic Resources in the library

\begin{tabular}{|c|c|c|c|c|c|c|}
\hline \multicolumn{7}{|c|}{ Awareness of Electronic Resources } \\
\hline \multirow[b]{2}{*}{ Academic Programme } & \multicolumn{2}{|c|}{ Yes } & \multicolumn{2}{|c|}{ No } & \multicolumn{2}{|c|}{ Total } \\
\hline & Freq & $\%$ & Freq & $\%$ & Freq & $\%$ \\
\hline Agricultural Technology & 7 & 63.6 & 4 & 36.4 & 11 & 100.0 \\
\hline B.ED Business Studies & 18 & 51.4 & 17 & 48.6 & 35 & 100.0 \\
\hline BE.D Social Science & 23 & 43.4 & 30 & 56.6 & 53 & 100.0 \\
\hline Development Education & 31 & 39.7 & 47 & 60.3 & 78 & 100.0 \\
\hline Early Childhood \& Basic Education & 18 & 60.0 & 12 & 40.0 & 30 & 100.0 \\
\hline Renewable Natural Resource & 11 & 68.8 & 5 & 31.2 & 16 & 100.0 \\
\hline SCC & 25 & 56.8 & 19 & 43.2 & 44 & 100.0 \\
\hline Total & 133 & 49.8 & 134 & 50.2 & 267 & 100.0 \\
\hline $\mathrm{N}=267, \mathrm{I}$ & 9.31 & x & & & .156 & \\
\hline
\end{tabular}

Source: Field Survey (2019)

Table 6. Access to Electronic Resources of the Library

\begin{tabular}{|c|c|c|c|c|c|c|}
\hline \multicolumn{7}{|c|}{ Access to electronic resources } \\
\hline & \multicolumn{2}{|c|}{ Yes } & \multicolumn{2}{|c|}{ No } & \multicolumn{2}{|c|}{ Total } \\
\hline Academic Programme & Freq & $\%$ & Freq & $\%$ & Freq & $\%$ \\
\hline Agricultural Technology & 4 & 36.4 & 7 & 63.6 & 11 & 100.0 \\
\hline B.ED Business Studies & 8 & 22.9 & 27 & 77.1 & 35 & 100.0 \\
\hline BE.D Social Science & 11 & 20.8 & 42 & 79.2 & 53 & 100.0 \\
\hline Development Education & 12 & 15.4 & 66 & 84.6 & 78 & 100.0 \\
\hline Early Childhood \& Basic Education & 13 & 43.3 & 17 & 56.7 & 30 & 100.0 \\
\hline Renewable Natural Resource & 4 & 25.0 & 12 & 75.0 & 16 & 100.0 \\
\hline SCC & 14 & 31.8 & 30 & 68.2 & 44 & 100.0 \\
\hline Total & 66 & 24.7 & 201 & 75.3 & 267 & 100.0 \\
\hline $\mathrm{N}=267$, Pearson Chi-sq & $=11.74$ & 6, Asy & ic Sig & $c e(p-r)$ & $=0.068$ & \\
\hline
\end{tabular}

Source: Field Survey (2019)

Further analysis was done to determine whether students had access to the electronic resources of the University library by asking them to indicate whether they had accessed the electronic resources. The results were presented in Table 6 . These showed that only 66 $(24.7 \%)$ respondents claimed that they had access to electronic resources. The remaining $201(75.3 \%)$ which constituted most of the respondents reported that they did not have access due to the lack of skills necessary to search the databases and hence have not been using the electronic resources of the library. Besides, the researcher wanted to know whether access to electronic resources of the library varied according to students' academic programmes of study. This was done by generating cross-tabulation of academic programmes and access to electronic resources. Frequencies and percentages (in parenthesis) were used to report the findings as shown in Table 6. The chi-square test results provided a test value of 11.74 and this was found to be not significant at $5 \%$ (p-value > 0.05). This means that the hypothesis of independence of access to electronic resources concerning academic programmes of study should be accepted. 
The relative frequencies and percentages shown in Table 6, suggest a variation in access to electronic resources of the library by students' academic programmes of study. Despite the generally low access of 66 (24\%), some programmes of the study had relatively lower access than others. For example, students pursuing Early Childhood and Basic Education had relatively higher access 13 (43.3\%). Besides, 4 (36.4\%) of students pursuing Agricultural Technology also had access and this is considered relatively better. However, students pursuing Development Education had relatively lower access to the electronic resources because only $12(15.4 \%)$ had access. Students pursuing Renewable Natural Resources, B.ED Social Science or B.ED Business Studies, all had lower access because less than $30 \%$ of had access to the University Library's electronic resources.

\subsection{Participation in IL Training Programme}

The University for Development Studies has Information Literacy training programmes for students to improve their information literacy skills. However, this training was considered an optional capacity building training for the students. The students who participated in this study were, therefore, asked to indicate whether they had ever participated in such an Information Literacy training programme. From Table 7, 76 (28.6\%) respondents had participated in the Information Literacy programmes while the remaining 190 (71.4\%) respondents had not participated in the programme. The results implied that the majority of the students had not participated in the Information Literacy programmes. Further, cross-tabulations were generated on participation in Information Literacy programmes by academic programmes being pursued. The independence of participation in the academic programme was tested using the Chi-square test. The test value (19.56, as reported in Table 7 was found to be significant at $5 \%$ (P-value $>0.05)$. This means that there was enough evidence to conclude that students' participation in the Information Literacy programme is influenced by a student's academic programme pursued. This conclusion can be defended considering the relative frequencies and percentages of participation by academic programmes as shown in Table 7.

From Table 7, there is a significant difference in students' participation in information literacy training by academic programmes being pursued. For example, in some of the academic programmes, students had a high level of participation while others did not. It was evidenced from Table 7 that students pursuing Agricultural Technology had 6 (54.5\%), and Renewable Natural Resources had 10 (62.5\%) levels of participation in Information Literacy programmes. On the other hand, low participation of students in Information Literacy programmes is associated with B.ED Business Studies, 8 (22.9\%), B.ED Social Science 10 (19.2\%) and Development Education.16 (20.5\%).

Table 7. Participation in Information Literacy Training Programme

\begin{tabular}{|c|c|c|c|c|c|c|}
\hline \multicolumn{7}{|c|}{ Participation in IL Training Programme } \\
\hline \multirow[b]{2}{*}{ Academic Programme } & \multicolumn{2}{|c|}{ Yes } & \multicolumn{2}{|c|}{ No } & \multicolumn{2}{|c|}{ Total } \\
\hline & Freq & $\%$ & Freq & $\%$ & Freq & $\%$ \\
\hline Agricultural Technology & 6 & 54.5 & 5 & 45.5 & 11 & 100.0 \\
\hline B. ED Business Studies & 8 & 22.9 & 27 & 77.1 & 35 & 100.0 \\
\hline B.ED Social Science & 10 & 19.2 & 42 & 80.8 & 53 & 100.0 \\
\hline Development Education & 16 & 20.5 & 62 & 79.5 & 78 & 100.0 \\
\hline Early Childhood \& Basic Education & 10 & 33.3 & 20 & 66.7 & 30 & 100.0 \\
\hline Renewable Natural Resource & 10 & 62.5 & 6 & 37.5 & 16 & 100.0 \\
\hline SCC & 16 & 36.4 & 28 & 63.6 & 44 & 100.0 \\
\hline Total & 76 & 28.6 & 190 & 71.4 & 267 & 100.0 \\
\hline $\mathrm{N}=267$, Pearson Chi-sc & $=19.56$ & Asy1 & C Signi & (p-va & 0.003 & \\
\hline
\end{tabular}


An interview with a library staff of the University for Development Studies confirmed that students have been participating in the Information Literacy programme as follows:

\section{Respondent 1}

"Yes, students have been attending Information Literacy Programme regularly because they have come to understand the importance of the programme. As a result, most of them can search and locate relevant information themselves."

The above statement implied that UDS students had developed a favourable attitude towards Information Literacy programmes as an academic course of study. Besides, the students are noticing the relevance of the programme because it improves their information literacy skills by facilitating their access to relevant information.

The respondents (students) had different opinions regarding their assessment of the effectiveness of the Information Literacy programme. From Table 8, the respondents had assessed the programme to be very effective, effective or ineffective. Generally, 36 (42.9\%) respondents indicated that the Information Literacy programme was very effective, while $39(46.4 \%)$ respondents indicated that the programme is effective. However, $9(10.7 \%)$ respondents shared their opinion that the programme was ineffective.

Table 8. Effectiveness of Information Literacy Programme

\begin{tabular}{|c|c|c|c|c|c|c|c|c|}
\hline \multicolumn{9}{|c|}{ Effectiveness of IL Training Programme } \\
\hline & \multicolumn{2}{|c|}{ Very effective } & \multicolumn{2}{|c|}{ Effective } & \multicolumn{2}{|c|}{ Ineffective } & \multicolumn{2}{|c|}{ Total } \\
\hline Academic Programme & Freq & $\%$ & Freq & $\%$ & Freq & $\%$ & Freq & $\%$ \\
\hline Agricultural Technology & 1 & 16.7 & 5 & 83.3 & 0 & 0.0 & 6 & 100 \\
\hline B.ED Business Studies & 5 & 35.7 & 4 & 28.6 & 5 & 35.7 & 14 & 100 \\
\hline BE.D Social Science & 6 & 60.0 & 2 & 20.0 & 2 & 20.0 & 10 & 100 \\
\hline Development Education & 7 & 41.2 & 8 & 47.1 & 2 & 11.8 & 17 & 100 \\
\hline Early Childhood \& Basic Education & 2 & 22.2 & 7 & 77.8 & 0 & 0.0 & 9 & 100 \\
\hline Renewable Natural Resource & 5 & 45.5 & 6 & 54.5 & 0 & 0.0 & 11 & 100 \\
\hline SCC & 10 & 58.8 & 7 & 41.2 & 0 & 0.0 & 17 & 100 \\
\hline Total & 36 & 42.9 & 39 & 46.4 & 9 & 10.7 & 84 & 100 \\
\hline
\end{tabular}

Source: Field Survey (2019)

Among the students pursuing Agricultural Technology, (1) 16.7\% considered the Information Literacy programmes as very effective, while (5) $83.3 \%$ considered it effective. This means that these students had at least attached importance to the programme once they had not considered it ineffective. Besides, students of B.ED Business Studies provided mixed opinions on the effectiveness of the Information Literacy programmes. It was discovered that (5) $35.7 \%$ of them considered the programme to be very effective, (4) $28.6 \%$ considered it to be effective and (5) $35.7 \%$ considered it ineffective. This means that this category of students was not very certain of their opinions regarding the effectiveness of the Information Literacy programmes. The results also revealed that more than half $6(60 \%)$ of students pursuing B.ED Social Science had rated the Information Literacy programme as very effective. Moreover, $2(20 \%)$ of them considered it as effective and the remaining $2(20 \%)$ indicated that it was ineffective. This means that majority of the respondents had at least considered the Information Literacy programme as effective for the improvement of their information literacy skills.

The results in Table 8 also revealed that students pursuing Development Education see the Information Literacy programme as at least effective in improving their information literacy skills. The results indicated that $7(41.2 \%)$ of them maintained that the programme is very effective and another $8(47.1 \%)$ said it is just effective. A smaller pro- 
portion $2(11.8 \%)$, however, claimed that the Information Literacy programmes are ineffective. Finally, students pursuing Early Childhood and Basic Education, Renewable Natural Resources, and Social Change Communication have all assessed the Information Literacy programmes as at least effective. This means that none of the respondents from these categories have considered the programme ineffective. Even though there were differences in opinions on the degree of effectiveness, the fact that none had considered it as ineffective underscores the effective role of the information literacy training programme in developing the information literacy skills of the students.

The results in Table 8 imply that the University's Information Literacy Programmes is effective in transforming the information literacy skills of the students. However, previous discussions suggest that students' participation in the programme was low relative to their assessment of its effectiveness. This also means that students own behaviours play a significant role in their information literacy skills development.

\subsection{Knowledge of Information Sources in the Library}

The respondents were asked to indicate their knowledge of information sources in the library that they can use to develop their information literacy skills. The results obtained are shown in Figure 3. This shows that the main information sources identified include the Encyclopedia, Directory, Almanac, Dictionary, Manual, and Handbook.

The distribution of these respondents revealed that $68(25.5 \%)$ respondents identified the Encyclopedia as a source of information in the Library, 35 (13.1\%) respondents cited the Directory as a source of information in the library. Furthermore, $21(7.9 \%)$ respondents mentioned Almanac, $63(23.6 \%)$ respondents identified Dictionary as an information source while $5.6 \%$ and $4.9 \%$ identified the Manual and the Handbook respectively.

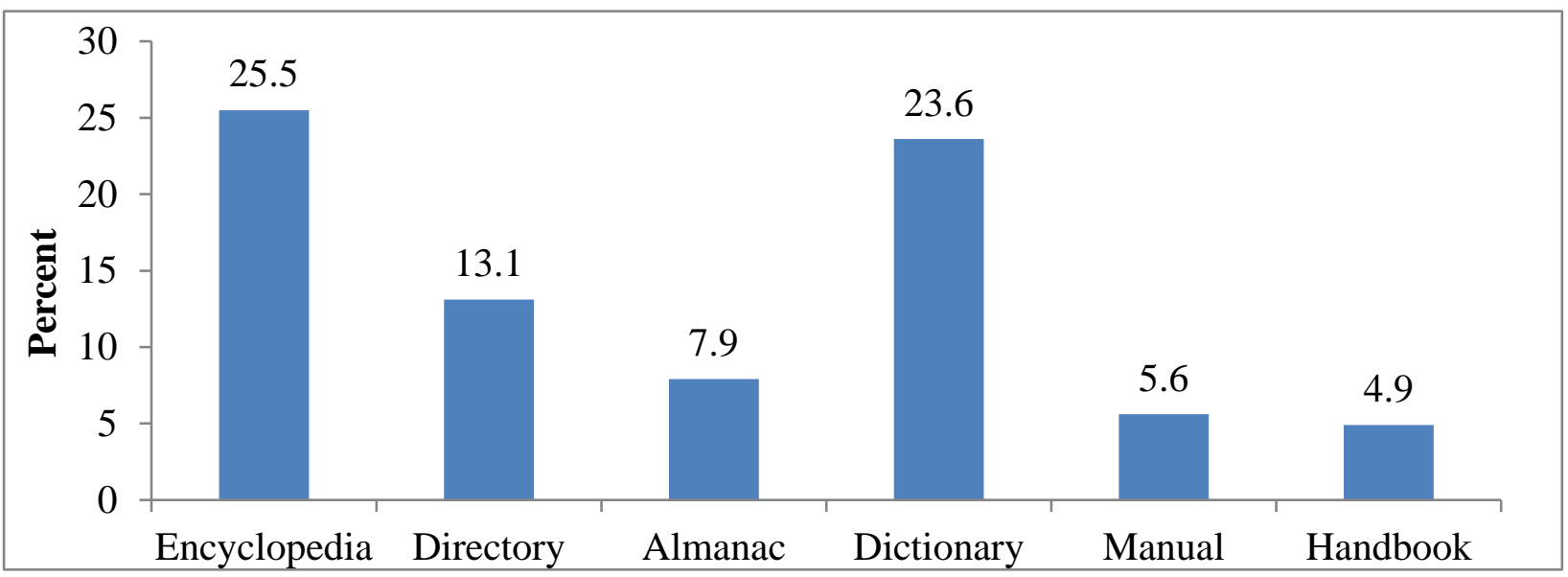

Figure 3. Information Source Available in the UDS Library. Source: Field Survey (2019)

The research also revealed that some sources of information are very relevant for some purposes. For example, students rely on various sources of information when finding background information for the research. The results, as shown in Table 9, indicate that $45(16.9 \%)$ of the respondents used the encyclopedia to obtain background information while $14(5.2 \%)$ used the directory. The majority 186 (69.6\%) of the students from various programmes gave no response to the question. The remaining sources, as shown in Table 9, were not widely used because the proportion of students using them was less than $5 \%$. This means that even though the students identified the sources in the table through which information could be sought, they were not very much relevant for background information. 
Table 9. Sources Used in Finding Information

\begin{tabular}{|c|c|c|}
\hline Source & Frequency & Percent \\
\hline Encyclopedia & 45 & 16.9 \\
\hline Directory & 14 & 5.2 \\
\hline Almanac & 3 & 1.1 \\
\hline Dictionary & 5 & 1.9 \\
\hline Manual & 9 & 3.4 \\
\hline Handbook & 5 & 1.9 \\
\hline No response & 186 & 69.6 \\
\hline Total & $\mathbf{2 6 7}$ & $\mathbf{1 0 0 . 0}$ \\
\hline
\end{tabular}

Source: Field Survey (2019)

Further evidence suggests that students use some specific sources of information to find names and addresses of people. This is common among 90 (33.7\%) respondents of the sample. Specific sources of information used to find names and addresses of people include encyclopedia, directory, almanack, dictionary, manual and handbook. Table 10 shows the distribution of respondents using such information sources in their search process. Additionally, $47(17.6 \%)$ of the respondents relied on a directory to find names and addresses of people, 4 (1.5\%) used the Encyclopedia,12 (4.5\%) used the Almanac, 8 (3.0\%) used the Dictionary, 13 (4.9\%) used the Manual, and 6 (2.2\%) used the Handbook. This shows that students used different sources of information to find the names and addresses of people.

The results in Table 10 imply that the students have not been using most of the information sources in the Library. For example, only $6(2.2 \%)$ students were found to be using handbooks, $4(1.5 \%)$ students used the encyclopedia and $8(3.0 \%)$ students used the dictionary in finding the names and addresses of people. One can argue that these sources may not be appropriate in finding names and addresses of people but the fact that even only $17.6 \%$ are using the directory to do so suggest low utilization of the information sources in the library.

Table 10. Source Used in Finding Names and Addresses of People

\begin{tabular}{|c|c|c|}
\hline Source & Frequency & Percent \\
\hline Encyclopedia & 4 & 1.5 \\
\hline Directory & 47 & 17.6 \\
\hline Almanac & 12 & 4.5 \\
\hline Dictionary & 8 & 3.0 \\
\hline Manual & 13 & 4.9 \\
\hline Handbook & 6 & 2.2 \\
\hline No response & 177 & 66.3 \\
\hline Total & $\mathbf{9 0}$ & $\mathbf{1 0 0 . 0}$ \\
\hline
\end{tabular}

Source: Field Survey (2019)

Data analysis also showed that some of the students relied on some specific information sources in finding meanings of words. From the study, the sources used by students included the encyclopedia and the dictionary. The distribution of this is shown in Table 11. The table indicates that $7(2.6 \%)$ of the respondents used an encyclopedia to find meanings of words, while $109(40.8 \%)$ indicated that they used the dictionary to find meanings of words. $56.6 \%$ had no response to the question. 
Table 11. Sources Used in Finding Meanings of Words

\begin{tabular}{|c|c|c|}
\hline Source & Frequency & Percent \\
\hline Encyclopedia & 7 & 2.6 \\
\hline Dictionary & 109 & 40.8 \\
\hline No response & 151 & 56.6 \\
\hline Total & $\mathbf{2 6 7}$ & $\mathbf{1 0 0}$ \\
\hline
\end{tabular}

Source: Field Survey (2019)

Further investigation revealed the sources of information used in finding miscellaneous information. These sources as shown in Table 12 included the Encyclopedia, the Directory, the Almanac, the Dictionary, the Manual, and the Handbook. The distribution in Table 12 shows that $10(3.7 \%)$ respondents used the encyclopedia to find miscellaneous information, $2(0.7 \%)$ respondents used the directory to find miscellaneous information, and $15(5.6 \%)$ respondents used the Almanac to find miscellaneous information. Furthermore, $20(3.7 \%)$ respondents used manuals while $12(4.5 \%)$ respondents used handbooks to find miscellaneous information. The majority $215(80.7 \%)$ of the respondents stated they used other sources to find miscellaneous information.

The results on sources used to find miscellaneous information imply that majority of the students have not been searching for such information using the sources provided in Table 12. This suggests a generally low utilization of library resources by students.

Table 12. Source Used in Finding Miscellaneous Information

\begin{tabular}{|c|c|c|}
\hline Source & Frequency & Percent \\
\hline Encyclopedia & 10 & 3.7 \\
\hline Directory & 2 & 0.7 \\
\hline Almanac & 15 & 5.6 \\
\hline Dictionary & 3 & 1.1 \\
\hline Manual & 10 & 3.7 \\
\hline Handbook & 12 & 4.5 \\
\hline Others & 215 & 80.7 \\
\hline Total & $\mathbf{2 6 7}$ & $\mathbf{1 0 0}$ \\
\hline
\end{tabular}

Source: Field Survey (2019)

Finally, the students were asked to indicate other sources from which they obtain information such as the names of countries and their presidents, international organizations, diplomatic lists, emergency telephone numbers etc. The sources they identified included encyclopedia, directory, almanack, dictionary, manual, and handbook. The distribution in Table 13 indicates that 10 (3.7\%) respondents obtained their information from the encyclopedia, $11(4.1 \%)$ respondents obtained their information from directory, 6 $(2.2 \%)$ respondents claimed that their source of information for finding other things such as useful website links, regional organisations etc. was the almanack. Moreover, respondents $2(0.7 \%)$ obtained their information from the dictionary, 39 (14.6\%) respondents also indicated that their source of information is manual and $8(3 \%)$ respondents obtained their information from handbooks.

The sources of the information shown in Table 13 suggests that only $28.5 \%$ of the respondents used these sources. There is, therefore, low utilization of information sources 
in the library and students were found to have a negative attitude towards information use. This will limit the development of information literacy skills among the students.

Table 13. Information sources

\begin{tabular}{|c|c|c|}
\hline Source & Frequency & Percent \\
\hline Encyclopedia & 10 & 3.7 \\
\hline Directory & 11 & 4.1 \\
\hline Almanac & 6 & 2.2 \\
\hline Dictionary & 2 & 0.7 \\
\hline Manual & 39 & 14.6 \\
\hline Handbook & 8 & 3.0 \\
\hline Others & 197 & 71.7 \\
\hline Total & $\mathbf{2 7 3}$ & $\mathbf{1 0 0 . 0}$ \\
\hline
\end{tabular}

Source: Field Survey (2019)

One way of seeking information is having access to the internet and the purpose for which one uses the internet. The respondents were asked to indicate whether they had access to the internet. The responses obtained were "Yes"," No" and "Sometimes". In all, $142(53.2 \%)$ respondents indicated that they had access to the internet, $47(17.6 \%)$ respondents indicated that they did not have access to the internet, while $78(29.2 \%)$ respondents also indicated that they sometimes had access to the internet.

The results in Table 14 also show access to the internet by students per their academic programmes of study. For example, among students pursuing Agricultural Technology 8 (72.7\%) had regular access to the internet, $2(18.2 \%)$ sometimes had access to the internet while only $1(9.1 \%)$ did not have access to the internet. Also, students of B.ED Business Studies were found to record low responses of $12(34.3 \%)$ who said they had access to the internet, $14(40 \%)$ indicated that they did not have access to the internet and $9(25 \%)$ attest that they sometimes had access to the internet. Data analysis revealed that 29 (54\%) students of B.ED Social Science had access to regular internet and 16 (30.2\%) sometimes had access. However, $8(15.1 \%)$ do not have access to the internet at all.

Table 14. Access to the Internet

\begin{tabular}{|c|c|c|c|c|c|c|c|c|}
\hline \multicolumn{9}{|c|}{ Access the Internet } \\
\hline & \multicolumn{2}{|c|}{ Yes } & \multicolumn{2}{c|}{ No } & \multicolumn{2}{c|}{ Sometimes } & \multicolumn{3}{c|}{ Total } \\
\hline Academic Programme & Freq & $\mathbf{\%}$ & Freq & $\mathbf{\%}$ & Freq & $\mathbf{\%}$ & Freq & $\mathbf{\%}$ \\
\hline Agricultural Technology & 8 & 72.7 & 1 & 9.1 & 2 & 18.2 & 11 & 100.0 \\
\hline B.ED Business Studies & 12 & 34.3 & 14 & 40.0 & 9 & 25.7 & 35 & 100.0 \\
\hline BE.D Social Science & 29 & 54.7 & 8 & 15.1 & 16 & 30.2 & 53 & 100.0 \\
\hline Development Education & 33 & 42.3 & 16 & 20.5 & 29 & 37.2 & 78 & 100.0 \\
\hline Early Childhood \& Basic Education & 22 & 73.3 & 1 & 3.3 & 7 & 23.3 & 30 & 100.0 \\
\hline Renewable Natural Resource & 9 & 56.2 & 1 & 6.2 & 6 & 37.5 & 16 & 100.0 \\
\hline SCC & 29 & 65.9 & 6 & 13.6 & 9 & 20.5 & 44 & 100.0 \\
\hline Total & $\mathbf{1 4 2}$ & $\mathbf{5 3 . 2}$ & $\mathbf{4 7}$ & $\mathbf{1 7 . 6}$ & $\mathbf{7 8}$ & $\mathbf{2 9 . 2}$ & $\mathbf{2 6 7}$ & $\mathbf{1 0 0 . 0}$ \\
\hline
\end{tabular}

Source: Field Survey (2019) 
The distribution of internet access by students pursuing Development Education revealed that $33(42.3 \%)$ respondents often had access to the internet and $29(37.2 \%)$ indicated that they sometimes had access to the internet. It was also found out that $16(20.5 \%)$ of this category of respondents did not have access to the internet at all. The results of internet access among students pursuing Early Childhood and Basic Education are impressive because the majority $22(73.3 \%)$ them indicated that they had access to the internet while 7 (23.3\%) sometimes had access. Only $1(3.3 \%)$ indicated that they did not have access to the internet at all. Further findings, as shown in Table 14, revealed that some students pursuing Renewable Natural Resources as well as those pursuing SCC had access to the internet as indicated by 9 (56.2\%) and 29 (65.9\%) respectively. On the other hand, $1(6.2 \%)$ and $6(13.6 \%)$ respondents did not have access to the internet respectively.

The respondents with access to the internet had a varying intensity of using this ICT tool. The results indicated that $168(63.2 \%)$ used the internet every day, $49(18.4 \%)$ used it once a week, $27(10.2 \%)$ used the internet twice a month and $22(8.3 \%)$ did not use it at all. From Table 15, 168 (63.2\%) respondents indicated that they used the internet every day, $49(18.4 \%)$ respondents indicated that they used the internet once a week, $27(10.2 \%)$ respondents said they used the internet twice every month while $22(8.3 \%)$ respondents were found not to be effective users of the internet. The results imply that majority of the respondents are at least regular users of the internet since 168 (63.2\%) had been using it every day.

Table 15. Frequency of Accessing the Internet

\begin{tabular}{|c|c|c|c|c|c|c|c|c|c|c|}
\hline \multicolumn{7}{|c|}{ How Often Do You Access the Internet } \\
\hline Programme & \multicolumn{2}{|c|}{ Everyday } & $\begin{array}{c}\text { Once a } \\
\text { week }\end{array}$ & \multicolumn{2}{c|}{$\begin{array}{c}\text { Twice a } \\
\text { month }\end{array}$} & \multicolumn{2}{|c|}{ Never used it } & \multicolumn{3}{c|}{ Total } \\
\hline Academic & Freq & $\%$ & Freq & $\%$ & Freq & $\%$ & Freq & $\%$ & Freq & $\%$ \\
\hline Agricultural Technology & 9 & 81.8 & 1 & 9.1 & 1 & 9.1 & 0 & 0.0 & 11 & 100.0 \\
\hline B.ED Business Studies & 17 & 50.0 & 8 & 23.5 & 4 & 11.8 & 5 & 14.7 & 34 & 100.0 \\
\hline B.ED Social Science & 30 & 56.6 & 12 & 22.6 & 5 & 9.4 & 6 & 11.3 & 53 & 100.0 \\
\hline $\begin{array}{c}\text { Development Education } \\
\text { Early Childhood \& Basic } \\
\text { Education }\end{array}$ & 24 & 62.8 & 14 & 17.9 & 6 & 7.7 & 9 & 11.5 & 78 & 100.0 \\
\hline $\begin{array}{c}\text { Renewable Natural Re- } \\
\text { source }\end{array}$ & 10 & 62.5 & 3 & 18.8 & 3 & 18.8 & 0 & 0.0 & 16 & 100.0 \\
\hline SCC & 29 & 65.9 & 8 & 18.2 & 5 & 11.4 & 2 & 4.5 & 44 & 100.0 \\
\hline Total & $\mathbf{1 6 8}$ & $\mathbf{6 3 . 2}$ & $\mathbf{4 9}$ & $\mathbf{1 8 . 4}$ & $\mathbf{2 7}$ & $\mathbf{1 0 . 2}$ & $\mathbf{2 2}$ & $\mathbf{8 . 3}$ & $\mathbf{2 6 6}$ & $\mathbf{1 0 0 . 0}$ \\
\hline
\end{tabular}

Source: Field Survey (2019)

Furthermore, internet use was analysed according to academic programmes of study and the results indicate that among all the programmes more than half of the students were found to have been using the internet every day. However, students who had not been using the internet at all were found to have been pursuing programmes in Education 
such as B.ED Social Science, B.ED Business Studies, and Development Education. Students pursuing programmes in the field of natural sciences were the least users of the internet.

It was discovered from the study that students accessed the internet for different purposes. They were, therefore, asked to indicate the various purposes for which they used the internet. From Table 16, $61(22.8 \%)$ respondents indicated that they used the internet for playing games. Besides, 186 (69.7\%) respondents $d$ indicated that they used the internet in searching for academic information. Results in Table 16 further indicate that 88 (33\%) respondents used the internet for e-mail communication while $100(37.5 \%)$ respondents used the internet for Facebook.

Table 16. Uses of the Internet

\begin{tabular}{|c|c|c|}
\hline Uses of the Internet & Frequency & Percent \\
\hline Use the internet in playing games & 61 & 22.8 \\
\hline Use the internet in searching for information & 186 & 69.7 \\
\hline Use the internet for e-mail & 88 & 33.0 \\
\hline Use the internet for Facebook & 100 & 37.5 \\
\hline
\end{tabular}

Source: Field Survey (2019)

Students make use of different search engines to access their needed information. Among these are Yahoo, Google, Wikipedia, and Alta Vista. The distribution in Table 17 indicates that $44(16.5 \%)$ respondents used Yahoo, 213 (79.8\%) respondents used Google, $63(23.6 \%)$ respondents used Wikipedia and only $6(2.2 \%)$ respondents used Alta Vista.

Table 17. Search Engines Frequently Visited by Student

\begin{tabular}{|c|c|c|}
\hline Search Engines & Frequency & Percentage \\
\hline Yahoo & 44 & 16.5 \\
\hline Google & 213 & 79.8 \\
\hline Wikipedia & 63 & 23.6 \\
\hline Alta Vista & 6 & 2.2 \\
\hline \multicolumn{2}{|c}{ Source: Field Survey (2019) }
\end{tabular}

\section{Discussion}

\subsection{Students' Access and Use of Information}

This section presents discussions on students' access and use of information. Key variables discussed included the frequency of visiting the library, purpose of visiting the library, library assistance, and awareness of electronic resources in the library. Other issues discussed under this section include students' participation in an information literacy programme, their knowledge of information sources, and access and use of the internet among the students.

\subsection{Frequency of Visiting the Library}

It was found out that some students visited the library every day, others weekly, some monthly, others once in a trimester, while some did not visit the library at all for academic information. The results implied that students had not considered the library as a source of vital academic information once their frequency of visiting it was low. Also, the proportion of students who used the library at least once a week was only $43.1 \%$ and this means that the remaining $56.9 \%$ either visited it once a month or not at all. This can limit their level of information literacy skills once access to vital information was not guaranteed. 
The results also suggest that students' academic programmes of the study influenced the frequency of library visits as supported by the Chi-square test analysis. For each of the academic programmes, a significant proportion of $66.3 \%$ of the students was found to have been visiting the library either once a week or once a month. This suggests that despite variations in the frequency of visits, there was generally low access to library information among the students. Despite the low attendance of students to the University Library, this finding confirms the results of [21] which states that some students still used the library resources to equally get information for their academic work or research. [7] had explained the low utilisation of library resources among students. In their view, the internet was serving as an alternative to traditional libraries (Libraries without modern technologies) because students could have access to information more conveniently in academic libraries without effective internet.

\subsection{Purpose of Visiting the Library}

The main purpose of students' visits to the library included reading different kinds of books, researching coursework, and searching for specific information when needed. The results suggest that students went to the library for general purposes, but their focus was on looking for academic information about their research or their coursework. It was also discovered that some $32.2 \%$ of students visited the library to read their notes and not purposely to search for information in the library. This means that students on the various campuses who accessed the library resources were making good use of the library. The results also imply that the university library has got facilities for students to do their private reading. Also, the library had a stock of academic materials that enabled students to search for information for research and coursework, read storybooks and any other special information that the students may need. This finding agrees with the work of Kimani [22] which emphasised that, aside from the library providing information to students for assignment, it also helped them in research and provided them recreational information materials. This means that the purpose of the University library in a way had been achieved since it was able to assist the students' access to relevant information for their academic activities.

The library had a variety of newspapers which included sports papers, political and entertainment papers. However, most students who visited the library did not use the newspapers. This finding also implies that the lack of non-essential materials in the University library limited access and use of academic information by students. This result also relates to the findings of empirical studies elsewhere in the world. For example, in Greece, [23] established that school libraries had not thrived for several reasons. Some of the reasons were that, libraries had not been treated as an integral part of the educational system and that they had not been connected to the teaching process; they had been regarded as redundant in a centralized as well as teacher-centred system, where teaching was limited to a single textbook. Such neglect could lead to a shortage of essential materials needed by students as in the case of this study.

\subsection{Library Assistance}

The main assistance received by students was in the area of activation of library cards, basic library ethics, browsing the automated catalogue, database research, accessing the library, how to borrow and return a book, how to retrieve information, general library orientation and instruction on research methodology. However, $48 \%$ of the respondents had not received any support in the form of instruction regarding using the library. This means that such affected students may likely not be active users of the library and hence may not even ask for any support from staff or the library staff are incapable of assisting users access library facilities. In either case, the information literacy skills of the students would be affected negatively. 
Some empirical studies had also identified a related challenge affecting users of libraries. For example, [24] pointed out the lack of proactive librarians and inadequate library staffing as challenges associated with access to library resources. Also, [25] reported on the failure on the part of librarians to push and assist students develop information literacy skills. This means that the low capacity of library staff to assist users in the library is a general challenge to the operations of the library. Such a general challenge had manifested itself in the University for Development Studies and is posing a limitation to students' access and use of academic information.

\subsection{Awareness of Electronic Resources and Databases}

The findings discovered that $133(49.8 \%)$ of the respondents were aware of the subscribed electronic resources and databases in the library. The proportion of respondents $134(50.2 \%)$ who were not aware of these resources was almost the same as those who were aware. However, only $66(24.7 \%)$ of the respondents had access to the electronic resources and the majority 201 (75.3\%) did not have access to the electronic resources due to various reasons. The findings also indicated that access to electronic resources of the library varies by students' academic programmes of study. Similar results were reported by [26] who discovered that users rarely used electronic resources such as Medline, Hinari, the Cochrane library and EbscoHost, possibly because of the lack of awareness and skills necessary to search the databases. This means that the 133 (49.8\%) awareness of electronic resources, as reported by this study, was not sufficiently large to stimulate more access to the library's electronic resources among the potential users.

The foregoing discussion had revealed that $133(49.8 \%)$ of the students who offered different programmes were aware of the electronic resources of the library but access to them turned out to be below. This means that students had not yet discovered the potentials of electronic resources for the development of their information literacy skills. It could also be that the library staff were not resourceful enough towards motivating students to use the electronic resources of the library.

\subsection{Participation in IL Training Programme}

Further, only 76 (28.6\%) of the respondents had participated in the Information Literacy (IL) programme while the remaining $190(71.4 \%)$ had not participated in the programme. The results imply that majority of the students had not participated in the IL Programme. Data analysis also showed that participation in information literacy training programmes was found to have an association with some academic programmes of study. For instance, students pursuing Renewable Natural Resources and Agricultural Technology had the majority participation in the programme, that was $6(54.5 \%)$ and $10(62.5 \%)$ respectively, showing the level of participation in the Information Literacy programme. On the other hand, low participation of students in the Information Literacy programme was associated with B.ED, Social Science 10 (19\%), Development Education 16 (20.5\%) and B.ED Business Studies $8(22.9 \%)$. This means that students pursuing programmes related to natural science participated more in information literacy programmes than those who pursued programmes in the social sciences.

The responses from previous studies did not match exactly with the findings of this research on the issues of students' participation in information literacy training. [3] explained that information literacy is an important component of any university library system because of its role in academic achievement and lifelong learning. As a result, library orientation was one way of educating students to be information literates. It involved taking the freshmen/women, or new students around the library and showing them the various sections of the library, where the catalogue is located, showing them the reference staff who would assist them when they needed help and other basic things about the library [4]. However, students' participation in such training programmes was low in the University for Development Studies. This could affect their information literacy skills (levels) and attitude towards information literacy programmes. 


\subsection{Knowledge of Information Sources in the library}

The respondents' knowledge of information sources available in the library for users to develop their information literacy skills was identified. The main information sources identified included encyclopedias, directories, almanacks, dictionaries, manuals, and handbooks. The students were aware of encyclopedias and dictionaries as sources of information than the other sources. This means that directories, almanacks, manuals and handbooks are not known by the majority of the students and these sources were likely not widely used. However, several studies by $[27,28]$ indicated that students relied mostly on the internet as their preferred source of information for academic work and research. It was revealed that the internet was mostly used because of its ease of access and could be used from everywhere, and the fact that it was convenient, and gave much information within a limited time. There was, therefore, a limitation on the part of the students (in this study) in respect of the use of library resources to improve their information literacy skills. Related findings had been reported in some empirical studies. For example, [21] identified that undergraduate students at Sultan Qaboos University used social media for academic purposes such as completion of course assessments and self-development in their academic specialities. Medical students in the College of Health Science in Niger Delta University, Nigeria mostly relied on textbooks, journals, the internet, colleagues and the National University Commission Libraries to identify their needed information (Baro \& Endouware, 2011). This means that similar sources of information as used by UDS students are being used elsewhere by other students.

The results also suggested that despite the low utilisation of information sources in the library about finding meanings of words, directions to places and the list of set of forthcoming events in the next year, the most common source used by the students was the dictionary. This was convincing since dictionaries have words and phrases with their meanings from which people could consult and make references, the encyclopedia was also relevant in finding meanings of words but the fact that the students were not using them meant that probably they were not very much aware of the potentials of the encyclopedia. Students were, therefore, limited in the utilisation of information sources of the library and this can affect the effective development of their information literacy skills.

\subsection{Access and Use of Internet}

The distribution of internet access by students pursuing Development Education revealed that $33(42.3 \%)$ often had access to the internet and $29(37.2 \%)$ maintain that they sometimes had access to the internet. It was also found out that $16(20.5 \%)$ of the respondents did not have access to the internet at all. Among all the programmes of study by the students, more than $50 \%$ of all the respondents were found to have been using the internet every day. Several studies by [27, 28] also mentioned that students relied mostly on the internet as their preferred source of information for academic work and research. However, students who had not been using it at all were found to have been pursuing programmes in the social sciences such as BE.D Social Science, B.ED Business Studies, and Development Education. Students pursuing programmes in the field of social sciences were the least users of the internet. Many scholars have tried to find ways by which students located their needed information. For instance, [29] conducted a study to explore how students evaluated themselves in certain information literacy skills. They found that majority of the students in Greek High School felt very capable of retrieving information from the internet. This means that many students in their studies had access to the internet.

The results of this implied that students accessed the internet for both academic and entertainment purposes such as social media and games. The use of the internet for a variety of purposes exposed the students to different kinds of information and this could be beneficial for the development of their information literacy skills. They also made use of different search engines to access their needed information. [30] stated that library and 
information science [31] students seem to be comfortable with developing search strategies, choosing search terms, and finding resources in libraries and on the Web. They relied heavily on search engines to express some concern about their ability to evaluate Web sources. This meant that the use of search engines was becoming popular among students in accessing their information needs. Additionally, [32] indicated that the most frequent source of information most of the undergraduates used for their course-related assignments and everyday life research was through search engines. This may be because these search engines had ease of use, the convenience of access and fast retrieval of information on the internet by browsing through web dictionaries. Such engines used by students in this study included Yahoo, Google, Wikipedia, and Alta Vista.

\section{Conclusion}

The results of the study had several implications for the development of information literacy skills in students and how the students perceived the information literacy programme in the University. The results implied that management of the University for Development Studies had made efforts to implement information literacy as an academic programme in four (4) out of the thirteen (13) Faculties. This effort had turned students' attention to how information literacy could be very beneficial in their lives.

The information literacy programme has given students some basic orientation on information access, recognition of good information, information retrieval and analysis. The various programmes such as freshers' orientation on library ethics and use of the library, as well as the periodic lectures on information literacy, are sources of skills development among the students. This means that the introduction of the information literacy programme had a positive influence on students' access to information and use of information.

\section{Recommendation}

The study offers the following recommendations to enhance the effective implementation of Information Literacy Programmes at the University for Development Studies.

\section{Enforcement of Academic Board Decision on IL Programmes}

Information Literacy is an approved programme by the Academic Board of the University for Development Studies. The Principals, Deans, University librarians and Heads of Academic Departments are all members of the Academic Board. The University Librarian should petition the Academic Board to direct the Faculties and Schools to implement the Information Literacy Programmes in all the Faculties, Schools and Departments of the University for the benefit of the students.

\section{There should be Coordination between Principals and Deans to Enforce IL Programme}

The study revealed that only four (4) out of the thirteen (13) Faculties and Schools offer the Information Literacy Programme in the University. This may be a result of the lack of interest in the programme among major stakeholders due to the programme load and insufficient lecturers to handle the programme. The Campus Principals and Deans should liaise with their counterparts from all the four (4) campuses and enforce the implementation of the Information Literacy Programme by making it compulsory for all students. This can be achieved by first recognizing the relevance and the need for the Information Literacy Programmes. This will influence Heads of departments and their staff to develop a favourable attitude towards the programme.

This can be done effectively when there is coordination between Principals and Deans to ensure that all the thirteen (13) Faculties and Schools comply and enforce the IL programme as part of the curriculum.

\section{Involve More Staff in the Teaching of the IL Programmes}

The study established that there are nine (9) qualified senior members at the post in the University library, yet only three (3) of them are involved in the teaching of the IL Programmes. The rest should also be assigned by the University Librarian to participate in the teaching of the programme. This 
will reduce the workload of the few teaching the programme. It will also enable the library to have a pool of available talents to handle such a programme.

\section{Data availability statement}

Data used for the study have all been included in the manuscript

\section{Conflict of interest}

The authors declare that, there is no any conflict of interest.

\section{Acknowledgements}

N/A

\section{Funding statement}

The study was self-funded

\section{References}

[1] Yeboah, P., P.S. Dadzie, and C.M. Owusu-Ansah, Information access and evaluation skills of secondary school students in Ghana. 2017.

[2] Fraillon, J., et al., IEA international computer and information literacy study 2018 assessment framework. 2019: Springer Nature.

[3] Anafo, P. and C. Filson, Promoting information literacy among undergraduate students of Ashesi University College. 2014.

[4] Dorvlo, S.S. and P.S. Dadzie, INFORMATION LITERACY AMONG POST GRADUATE STUDENTS OF THE UNIVERSITY OF GHANA. Library Philosophy \& Practice, 2016.

[5] Hatlevik, O.E., et al., Students' ICT self-efficacy and computer and information literacy: Determinants and relationships. Computers \& Education, 2018. 118: p. 107-119.

[6] Okeji, C.C., O.M. Ilika, and E.E. Baro, Assessment of information literacy skills: A survey of final year undergraduates of library and information science in Nigerian universities. Global Knowledge, Memory and Communication, 2020.

[7] Keshalu, P. and V. Srinivasulu, Awareness of information literacy among undergraduate students of ParitalaSriramulu Government Degree College: Penukonda. International Journal of Research in Library Science, 2016. 2(2): p. 109-115.

[8] Abbas, A., et al., Research ethics dilemma in higher education: Impact of internet access, ethical controls, and teaching factors on student plagiarism. Education and Information Technologies, 2021: p. 1-13.

[9] WHO, Estimating the burden of foodborne diseases: a practical handbook for countries: a guide for planning, implementing and reporting country-level burden of foodborne disease. 2021.

[10] Olukemi, O.O., Challenges of information literacy skills of undergraduate students in Ajayi Crowther University, Oyo State Nigeria. Zarządzanie Biblioteką, 2019(1 (11)): p. 111-123.

[11] Lwehabura, M.J.F., An assessment of information literacy skills among first-year postgraduate students at Sokoine University of Agriculture Tanzania. Journal of Librarianship and Information Science, 2018. 50(4): p. 427-434.

[12] Passey, D., et al., Digital agency: Empowering equity in and through education. Technology, Knowledge and Learning, 2018. 23(3): p. 425-439.

[13] Kumar, P., What is descriptive research method. 2011.

[14] Apuke, O.D., Quantitative research methods: A synopsis approach. Kuwait Chapter of Arabian Journal of Business and Management Review, 2017. 33(5471): p. 1-8.

[15] Creswell, J.W. and J.D. Creswell, Research design: Qualitative, quantitative, and mixed methods approaches. 2017: Sage publications.

[16] Saputra, K.A.K., et al., Management of Village Original Income in The Perspective of Rural Economic Development. International Journal of Advances in Social and Economics, 2019. 1(2): p. 52-59.

[17] Yebowaah, F.A. and F.D.D. Plockey, Awareness and Use of Electronic Resources in University Libraries: A Case Study of University for Development Studies Library. Library Philosophy \& Practice, 2017.

[18] Shulman, R.G., et al., Nuclear magnetic resonance determination of ligand-induced conformational changes in myoglobin. Journal of molecular biology, 1970. 53(1): p. 143-157.

[19] Adam, J. and F. Kamuzora, Research methods for business and social studies. Mzumbe book project, 2008.138.

[20] Etikan, I. and K. Bala, Sampling and sampling methods. Biometrics \& Biostatistics International Journal, 2017. 5(6): p. 00149.

[21] Al-Aufi, A.S., H.M. Al-Azri, and N.A. Al-Hadi, Perceptions of information literacy skills among undergraduate students in the social media environment. International Information \& Library Review, 2017. 49(3): p. 163-175.

[22] Kimani, E.N., Challenges in quality control for postgraduate supervision. International Journal of Humanities Social Sciences and Education, 2014. 1(9): p. 63-70.

[23] Malliari, A., et al., Information literacy skills of Greek high-school students: Results of an empirical survey. Qualitative and Quantitative Methods in Libraries, 2017. 3(1): p. 271-281.

[24] Bawack, R., Academic Libraries in Cameroon in the digital age. Libr Philos Pract, 2019. 2019: p. 1-13. 
[25] Widén, G., et al., Workplace information literacy: Measures and methodological challenges. Journal of Information Literacy, 2021. 15(2).

[26] Kwafoa, P., K.A. Barfi, and E.M. Agyapong, Use of electronic resources by postgraduate students in University of Cape Coast. 2019.

[27] Sutherland, S. and A. Jalali, Social media as an open-learning resource in medical education: current perspectives. Advances in medical education and practice, 2017. 8: p. 369.

[28] Apuke, O.D. and T.O. Iyendo, University students' usage of the internet resources for research and learning: forms of access and perceptions of utility. Heliyon, 2018. 4(12): p. e01052.

[29] Nitsos, I., et al., Information literacy skills of Greek high-school students: results of an empirical survey. 2014.

[30] Saunders, L., et al., Information behaviors and information literacy skills of LIS students: an international perspective. Journal of education for library and information science, 2015. 56(s1): p. 80-99.

[31] Porter, J.A., et al., Integration of information and scientific literacy: promoting literacy in undergraduates. CBE - Life Sciences Education, 2010. 9(4): p. 536-542.

[32] Sriborisutsakul, S., et al., Undergraduate Students' Information Literacy Behaviour in Chulalongkorn University. 2012. 